\title{
INHABITING THE BRITISH COUNTRY HOUSE IN INDIA: THE INHERITANCE OF LOSS BY KIRAN DESAI
}

\author{
Natacha Lasorak, École Normale Supérieure de Lyon, \\ natacha.lasorak@ens-lyon.fr
}

DOI: $10.31902 /$ fll.31.2020.4

UDK 821.111.09-31

\begin{abstract}
Kiran Desai's critically acclaimed novel, The Inheritance of Loss, intertwines narratives of the lives of three characters: the judge, haunted by his past, is joined by his granddaughter Sai in his house in north-eastern India, while the son of his cook is working illegally in America. Published in 2006, the novel has mostly been analysed in the light of diaspora studies and praised for its author's questioning of the effects of globalisation and immigration when leaving home. Yet what is also worth examining is the way in which some of the characters of the novel, including the judge, inhabit their chosen homes as foreigners or, to be more specific, as surrogate Britons in their country of origin, creating a separate community of anglophiles. The "solace of being a foreigner in [their] own country" (29) is but one of their rewards in their attempts at mimicking a British way of life. If the houses of the novel are set in independent India, this article questions the extent to which they could be read as counterparts to the British country house, relating them to values of continuity, tradition and Englishness. While anglophile characters take the British country house as model for their own Indian houses, their nostalgia is for a British home they never knew or owned. Their experiences of immigration can only lead them to create a pastiche of an English country house, which relies on a mythified vision of England. Their acceptance of English values and social hierarchy turns them into foreigners in their own country, seemingly blurring the definitions of "home" and "abroad". Their reliance on the model of the British country house further points to the ways in which The Inheritance of Loss parodies the genre of the English manor house novel and the way it relies on colonialist norms.
\end{abstract}

Keywords: home, country house, nostalgia, manor house novel, postcolonial literature.

The Inheritance of Loss is Kiran Desai's second novel. Set in the 1980s, it weaves together three Indian lives, two of which encapsulate movements of migration out of India and narratives of return. The judge, Jemubhai, left his parents' house as a young man before the Independence of India to study law in Cambridge, where he suffered from racism and exclusion. However, coming back to India in 1944, the 
prestige of having studied in the United Kingdom propelled him to a position of power in the judiciary from which he has now retired. His orphaned teenage granddaughter Sai has joined him to live with him in Kalimpong, a small hill station in the Himalayas. The judge, Sai and his cook live a quiet life in a crumbling country house until Kalimpong is shaken by the Gorkha National Liberation Front's (GNLF) demand for a separate state of Gorkhaland. Intertwined in the fabric of the text is the story of the immigration of Biju, the cook's son, to the United States, as he struggles to earn money as an illegal worker and finally gives up.

Desai's novel seems to suggest two ways of dealing with going away from home. While the judge is prone to idealise England despite his humiliating experience as a student, Biju constantly questions the necessity of being away from one's homeland:

This way of leaving your family for work had condemned them over several generations to have their hearts always in other places, their minds thinking about people elsewhere; they could never be in a single existence at one time. (311)

The metaphor of having one's heart in another place emphasises the character's nostalgia. In Ethics and Nostalgia in the Contemporary Novel, John J. Su reminds his readers of the etymology of the term: 'two Greek roots: nostos, 'return to one's native land,' and algos, 'pain'", and defines nostalgia as the "longing to return to [one's] homeland" (1). Robert Browning explores this feeling in his poem "Home-Thoughts, from Abroad," a dreamy reflection on the country he has left, in which he expresses his nostalgia and regrets his being away from home ("Oh, to be in England"). Italy, with its "gaudy melonflower," cannot compare with the country of his birth, England, which is perceived as the ideal place to which the poet wants to come back.

In the context of postcolonial studies, "home-thoughts" and the sense of longing are complicated by the notion of belonging. The stories of exile and immigration are intertwined with the faltering principles of allegiance to one's native country, especially when this country has been colonised by another. Hence the "home-country," or motherland, does not always correspond to the country of one's birth. Nostalgia, when it arises, sometimes finds a different object, for example when the wish to belong is directed towards the colonising power. In V. S. Naipaul's novel, The Mimic Men, the protagonist's allegiance is to England, despite his Indian origins. In The Inheritance of Loss, the experience of immigration and colonisation triggers similar 
reactions of mimicry, which this study will examine in relation to Homi Bhabha's analysis of the concept in The Location of Culture.

In The Inheritance of Loss, nostalgia is not as clear as in Browning's poem, for a whole group of anglicised Indians living in Kalimpong dream of England as a theoretical country of adoption that they have chosen but in which they do not live. Tellingly, they have selected the model of the British country house for their own accommodation. However, their nostalgia for imagined old-fashioned traditions and rigid social codes of behaviour underlines the artificial quality of the feeling. In Su's words, nostalgia is "a longing for a past that never was" (3) and the characters' dream is indeed of England as it may have been: their ideal is anchored in an imagined past which is mainly produced by artistic visions (notably through films and literature).

Drawing on postcolonial studies and postmodern theory, our analysis of Desai's novel will show how the focus of nostalgia shifts from India to England, reverting the notions of "home" and "abroad." We will, however, question the limits of such an inversion through the study of the country house and examine the extent to which Desai subscribes to the associated genre of the "country house novel" (or "manor house novel") in The Inheritance of Loss.

\section{Blurred national identities: "a foreigner in his own country"}

Immigration is a powerful experience which affects the identity of the immigrant and his sense of belonging. In his collection of essays Imaginary Homelands, the Indian-born British writer Salman Rushdie underlines the importance of the confusion in a significant formula: "Our identity is at once plural and partial. Sometimes we feel that we straddle two cultures; at other times, that we fall between two stools" (15). This in-betweenness seems to be the epitome of the immigrant experience. Neither completely here nor there, the immigrant is on the margins of both. What is particularly interesting in The Inheritance of Loss is that this position is chosen by an immigrant character once he has returned to his home country. After his retirement, the judge decides not to merge into the society of Kalimpong but chooses to remain alone except for his dog, his cook, and his granddaughter whose presence he first fears. The refusal to integrate is summarised when he first visits the house in 1957: "The judge could live here, in this shell, this skull, with the solace of being a foreigner in his own country, for this time he would not learn the language" (29). The 
identification of the judge as "a foreigner in his own country" questions the very definition of "foreigner," for if the judge comes from a different region of India, his nationality is still Indian. Is the term here to be interpreted metaphorically, as someone who does not belong? The use of the word "foreigner" reveals a detachment which underpins the way the judge considers himself. The Oxford English Dictionary online reveals that "foreign" comes from the Latin foris, meaning "outside," itself deriving from fores, "door," hence to be foreign literally means to be on the other side of the door. Yet in The Inheritance of Loss, it is primarily by staying indoors that the judge can affirm his "foreignness" and his detachment from the rest of Kalimpong.

The judge's behaviour and adherence to a British way of life suggest that his alienation is the result of his experience abroad. His estrangement, the reader is told, dates back from his return from England: "He was a foreigner - a foreigner - every bit of him screamed. Only his digestion dissented and told him he was home" (166-7). The reference to the judge's digestion may remind us of a short story called "Squatter" by the Indian-born Canadian writer Rohinton Mistry. "Squatter" introduces a character, Sarosh, for whom "complete adaptation to the new country [Canada]" equals the ability to use the Western toilets. The parallel between the two texts suggests that although characters may reach a degree of "adaptation," there are certain elements on which they cannot act. At the end of "Squatter," Sarosh goes home to India after a self-imposed ten-year time limit, still a foreigner in Canada. Sarosh's experience, as well as the judge's in The Inheritance of Loss, convey an idea of the limits of adaptation to another country and also point to the superficiality of personality changes, for both characters, despite having spent years in a Western country, seem to have remained Indian inside.

As a result, the judge in Desai's novel engages in an extensive mimicry of all the things on which he can act so that he may feel completely adapted to the former colonising power. Critics have extensively commented on the judge's anglophile way of life - his use of English, his fondness for tea, his demand that Sai uses knife and fork to eat, even chapatis, or his use of powder to cover his face, like a British gentleman. Lucienne Loh's article, which offers a comparison between this novel and Julian Barnes' England, England, analyses the ways in which English heritage is commodified in The Inheritance of Loss, so that socially privileged characters can "signify their relative wealth and social status within the village's social hierarchy" (310). The 
search for social power is at the core of the judge's imitation of what he deems an English way of life.

The judge becomes thus a defender of the former coloniser's culture and a true "mimic man," echoing Homi Bhabha's definition of the desire for mimicry in the colonial discourse: "colonial mimicry is the desire for a reformed, recognizable Other, as a subject of a difference that is almost the same, but not quite" (86, emphasis in the original). Bhabha goes on to quote the British politician Macaulay who served on the Supreme Council of India and wrote a "Minute on Indian Education" (1835) in which he wished to create "a class of interpreters between us and the millions whom we govern - a class of persons Indian in blood and colour, but English in taste, in opinions, in morals and in intellect"1 (87). The establishment of English tastes, values and education as so clearly superior to the Indian ones transpires in the judge's way of life, who aspires to a complete identification to the British, but remains necessarily "Indian in blood and colour": his attempts are thus limited to repetition, or mimicry of the British gentleman.

In this endeavour the judge is joined by a whole community of anglophiles, who has gathered in Kalimpong, featuring in particular two old sisters from Calcutta named Lola and Noni, a Swiss priest and a drunk farmer. During the political unrest arising in the narration, the Swiss priest, Father Booty, is discovered to not have a valid residence permit: "Father Booty was now found to be residing in India illegally. [...] He knew he was a foreigner but had lost the notion that he was anything but an Indian foreigner" (220). Being part of the group of anglicised Indians living in Kalimpong, Father Booty is aware of the fact that he does not completely belong, in the same way as Sai or the judge do not belong. His surprise comes from his realisation that his lack of an Indian passport sets him apart from the other anglophiles, making him a "foreigner" in a legal sense, not only on a sentimental level.

From the beginning of the novel to its end, it is thus made clear that the community of anglophiles who has gathered in Kalimpong is united by their common sense of feeling like "foreigners." Whether they are thus legally (such as Father Booty or the two Afghan sisters who live nearby) or not (such as the judge or Lola and Noni) does not prevent them from sharing a similar way of addressing their identity,

1 Thomas Babington Macaulay, "Minute on education," in W. Theodore de Bary, ed. Sources of Indian Tradition, vol. II. New York: Columbia University Press, 1958, p. 49. 
relying on a British way of life and on its most obvious manifestation in The Inheritance of Loss: the choice to live in a British country house.

\section{Cho Oyu: a British country house?}

In this context, it is no surprise that the British country house should be sought after by the characters. For what could be more British than the country house? In his collection of essays English Hours, the American writer Henry James defines the country house as quintessentially British:

Of all the great things that the English have invented and made part of the credit of the national character, the most perfect, the most characteristic, the only one they have mastered completely in all its details, so that it becomes a compendious illustration of their social genius and their manners, is the wellappointed, well-administered, well-filled country house. (273)

From the onset, the country house is related to the English "national character," the very epitome of Englishness. John Su also notices how the English estate has, since the beginning of the nineteenth century, been a crucial site of cultural debates about national identity in literature (123).

Set in India, however, the country house can only be but a pastiche of its British counterpart. In her study A Theory of Parody, Linda Hutcheon defines pastiche which, for her, stresses "similarity rather than difference" (33), and is thus a production of the same genre as its model involving an imitative approach. The house named Cho Oyu that the judge finds for himself is an imitation built by a "gentleman," a Scotsman whose representation of the country house is close to the British ideal described by Henry James. Cho Oyu is a large mansion which is repeatedly described as impressive:

Cho Oyu might be crumbling, but it had once been majestic; it had its past if not its future, and that might be enough - a gate of black lace, the name worked into imposing stone pillars with mossy cannonballs on top as in To the Manor Born. (257)

If the house is frequently described as unfit for habitation - eaten away by insects (34) or swelling with water during monsoon season - it is nevertheless praised for its past grandeur. Here the country house meets the requirements of its equivalent on the English soil; according 
to $\mathrm{Su}$, "[t]he endurance of the estate creates the illusion of national continuity" (123). The maintenance of a British country house in India underlines the permanence of a colonial state of mind. After Independence, although national continuity is broken, it seems that relying on Cho Oyu is a way to emphasise and exaggerate the perpetuity of the past, although, as we shall analyse later in this article, signs of its decline are already visible (the house is "crumbling," covered in moss, and is no longer "majestic"). In his study of the country house in English literature, Malcolm Kelsall reminds us of the importance of this past which is summarised in the motto: "Not make it new, but make it old" (92). The visual description of Cho Oyu highlights the way in which it replicates the type of house presented on British television, and associates it to an imagined place, as it is here compared to the BBC series To the Manor Born (1979-81), featuring the life of a widow who has to sell her manor after her husband's death. This reference to a product of popular culture, widely broadcast underscores the narrator's irony as it contrasts with the protagonists' feeling of cultural superiority (expressed through their references to canonical literature throughout the novel), and suggests a widespread fascination for the decaying houses threatened by the financial struggles of the aristocracy.

The country house in the passage quoted above seems to represent a true symbol of Englishness, yet it should be noted that this development is fairly recent. Peter Mandler, in his historical study The Fall and Rise of the Stately Home, dates the establishment of the country house as a characteristic piece of English art back to the 1930s, when a few British aristocrats, eager supporters of Georgian architecture, attempted to promote it as such to better defend it (289). These attempts were the first steps towards the recognition that country houses had gained by the 1970s:

Suddenly, it had become a national symbol of sorts, as "essential" as anything can be in the diversity of late twentiethcentury life, and so of course it became the object of a myth the country house had "always" enjoyed its contemporary status - the "tradition" of the country house standing for England had been invented. (Mandler, 401)

The authentic character of the country house cannot therefore be taken for granted; it is the result of a historical process which derives from class interests and a political agenda. In The Inheritance of Loss, 
the judge's and his neighbours' reliance on such ideals betrays the counterfeited character of their social superiority.

Yet the artificiality of the image cannot hinder the power of the house as incarnating a certain foreign ideal. The name "Cho Oyu" comes from the name of a peak which culminates at the frontier between Nepal and Tibet and indeed, stepping into Cho Oyu implies entering another space, out of Kalimpong, for the house is far from the city center. In this regard, Cho Oyu fulfills the demands of the country house or "estate house" as defined by Mandler, who explains that the establishment of country houses until the middle of the eighteenth century away from the rest of the community created "new houses cut off from both the past and the people" (7). Mandler further states that in the nineteenth century, the label "stately home" implied both familiarity and distance, or even arrogance (63-64). In this as in other aspects, The Inheritance of Loss can be seen as a rewriting of Anita Desai's Fire on the Mountain in which the main character, Nanda Kaul, has settled in a house built during colonial times by Colonel Macdougall (1843) and occupied by English people until her arrival. Nanda Kaul's desire for such a house (like the judge's in The Inheritance of Loss) is motivated by the house's aloofness, which is enhanced in both novels by the position of the house in hill resorts. The marginality of Cho Oyu in The Inheritance of Loss and of Nanda Kaul's house in Fire on the Mountain is thus the result of conscious choices which encapsulate these desires.

For the judge, the house functions as a portal to another mysterious dimension: "[The judge] knew he could become aware here of depth, width, height, and of a more elusive dimension" (29). His granddaughter Sai's feelings are not different in this regard: "[Sai] had a fearful feeling of having entered a space so big it reached both backward and forward" (34). This unnamed, invisible quality of Cho Oyu is not only to be seen but also to be felt. The "more elusive dimension" as well as reaching "backward and forward" seem to imply that the house gives way to another space and perhaps another time which finds its roots in the colonial past. The house is also a way to enter a greater natural order, which is what seduces the judge on his first visit. His awe at the discovery of Cho Oyu is indeed aroused by its "monastic light" (28), its ceiling which is compared to "the rib cage of a whale" (29) and the presence of the Himalayas whose peaks "proved a man to be so small that it made sense to give it all up, empty it all out" (29). The appeal to spiritual ("monastic"), animal ("whale") and mineral ("Himalayas") grandeur is reinforced by the strong presence of plants: "ferns," "foliage," "curly nubs" are developing at the windows, giving 
the impression that the house is blending with the landscape and the soil, thereby echoing Kelsall's view according to which the country house in English literature often becomes "a natural excrescence" (6). The house also conveys a certain spirituality which underlines the judge's distance from the material world of Kalimpong and reminds us of the judge defining himself as "foreigner": by choosing to remain in Cho Oyu, barely leaving the house (the car has not been used since a month before Sai's arrival, the narrator notices), the judge appears as a static character who threatens to turn into a hermit.

The description of Cho Oyu makes it clear that the judge has found a home, a place where he belongs, precisely because it is rooted in a colonial past and an imitation from a British model. Through the nostalgic maintenance of traditions such as the British ritual of fiveo'clock tea, he attempts to inscribe Cho Oyu in a line of British country houses. Thus, he becomes the bearer of these traditions, as Su has noted: "[i]f the estate itself is the physical marker of the national spirit or èthos, then its lord has a responsibility to be both guardian and representative of Englishness" (126). This role is duly accepted by the judge who notably enforces what have been deemed English customs. For instance, during a dinner with Gyan, Sai's mathematics tutor and future Ghorka independentist, the judge arbitrarily renames him Charlie (an English name) and forces him to eat with fork and knife and to recite a poem (109). His authority derives not only from his age or position as a patriarch but overtly from his higher knowledge of a supposedly superior British culture.

However, signs of downfall clearly establish Cho Oyu as dysfunctional, starting with the tea ritual itself which has become a "travesty [which undoes] the very conception of teatime" (3), as the judge himself recognises. A comparison with Kazuo Ishiguro's The Remains of the Day may prove relevant here as both Darlington Hall (the country house in which Stevens is a butler) and Cho Oyu host only a small number of servants: Stevens has seen his staff being reduced and with it, the dignity of Darlington Hall, and the cook in The Inheritance of Loss is the only member of staff in Cho Oyu, which points to the loss of grandeur of the house. Ironically, the cook is particularly critical of this, as his working for an Indian judge comes as a downfall from his own line of work: "A severe comedown, he thought, from his father, who had served white men only" (63). Stevens' situation in The Remains of the Day is not more enviable, as Darlington Hall has been sold to an American, depriving him of the privilege of working for a British aristocrat. Although the characters of Ishiguro's and Desai's novels are not subjected to the same treatment 
(the narrator in The Inheritance of Loss shows more irony as a critical distance with the cook is established from the start of the novel), the parallels between the two novels are underscored by their titles, which highlight a notion of decay. In The Inheritance of Loss, this decline, of which the physical deterioration of Cho Oyu is a symbol, is also that of imperialism, as is the case in another Indian novel, Arundhati Roy's The God of Small Things. In Roy's novel, the house of an Englishman who has "gone native" and then committed suicide is left to rot; for the children, it is the History House, a place which gives access to the past for those who can enter it, peopled with "waxy, crumbling ancestors with tough toe-nails and breath that smelled of yellow maps gossip[ing] in sibilant, papery whispers" (53). As for Cho Oyu, Roy's History House is the site of a disappearing past, where the ancestors' "crumbling" suggests that the walls will not hold for a long time, where maps take on the sepia tones of days gone in a subtle reference to the redrawing of borders after Independence. If the young characters of The God of Small Things are denied access to the History House, in The Inheritance of Loss, the judge who has managed to step inside Cho Oyu can only maintain the facade of a house which is crumbling from inside.

I would argue that the decline of the country house is further exploited by Desai in the ironical subversion of the codes of the "manor house novel," which intimates that the nostalgia the characters feel for the British country house is misplaced and ethically condemned.

\section{The fall of the English country house through the parody of "manor house novels"}

As The Inheritance of Loss tackles rituals, power relations and the rise of political tension in the background, the authenticity of the British country house is put into question in a revision of the literary genre which is so highly praised by Sai and her friends. The characters relish "best of all [...] manor house novels" (198) and references to such novels are numerous in the book, for instance Emily Brontë's Wuthering Heights (218), Charlotte Brontë's Jane Eyre (119), and "all of Jane Austen" (44). Literature and film have taken the value of models for the characters' lives, and Sai herself recognises in novels about traveling in India the story of her own arrival in Cho Oyu (199).

These references emphasise the artificiality of the characters' dream of living in a fictive place and of the subject of their nostalgia. If their houses are pastiches of the British country houses, the novel 
plays with parody in the way Hutcheon defines it: "a form of imitation, but imitation characterized by ironic inversion" (6). This inversion takes place from the very title of the novel for if manor house novels are about inheritance, the material object of legacy is replaced by loss. A reading of the novel in comparison with Jane Austen's Mansfield Park underlines the way The Inheritance of Loss could be read as a Bildungsroman for the character of Sai, while suggesting a parody of the model provided by Austen. In Mansfield Park, the protagonist, Fanny, has been welcomed in her sometimes broody uncle's house in the countryside, where she grows up to develop the authentic manners of an English lady, under the careful eyes of her two aunts. The plot of Desai's novel shows strong similarities with that of Austen's but the detachment from the manor house novel genre is obvious in the way Sai's life constantly refuses a "happily ever after" ending. The narrator ironically blends in a feature of the fairy tale: "[Sai's] kiss had not turned [Gyan] into a prince; he had morphed into a bloody frog" (248). The intrusion of the failed fairy tale provides a comment on the manor house novel, emphasising Desai's novel's departure from the usual plot, which gives way to a reflection on the ethics of maintaining a British country house in India through political trouble.

The traditional country house novel usually shies away from the noises of the city and news of the world. In Desai's novel, however, the political events which shake Kalimpong strongly affect life in the country house and the very beginning of the novel testifies to the intrusion of political life inside it. In the first pages of the novel, the house is being robbed and the robbers invite themselves to stay for tea in Cho Oyu (5) in a reversal of traditional manners which turns the tea ritual into a parody. The political context in which the narrative is set questions the legitimacy of the characters to own country houses, and the temporary invasion of Cho Oyu by the robbers is echoed by the later occupation of Lola and Noni's garden by Gorkha independentists. This event leads the sisters to reflect: "It did matter to live in a big house and sit beside a heater every evening [...] it did matter that others could not" (242). This small epiphany, in which they realise that their decision to inhabit a comfortable pretty cottage is the result of a class privilege, contrasts with their usual fascination for a British lifestyle at any cost. For once, they are allowed an outsider's view on their own wealth and the nostalgia that they usually display (in their compulsive collection of After Eights, Marks and Spencer panties or daffodil bulbs) appears in all its artificiality, for it has clearly turned here into the preservation of a privileged educated class which is no longer deemed acceptable. 
In such occurrences, The Inheritance of Loss echoes The Remains of the Day in its questioning of the legitimacy of characters to protect "Englishness," which Stevens has accepted as his duty. In The Inheritance of Loss, although Lola and Noni's experience of England is limited to their trips to visit Lola's daughter Pixie in London, the nostalgia that they feel for a British way of life has led them to live a life disconnected from the reality of the place and time in which they live. Thus, Englishness has become, as Su puts it in his analysis of Ishiguro's novel, "an empty signifier deployed to legitimate particular ideological positions" (131): "[p]recisely because the term [Englishness] does not signify anything specific, it can be used to justify any number of unrelated goals" (131). In The Inheritance of Loss, the invasion of the sisters' garden by GNLF rioters suggests that the defence of the country house becomes impossible in the new political context, which questions the established economic order.

Contrarily to Ishiguro's novel, however, the fact that the United States gain importance in the economic world order does not lead to the downfall of British ideals but to new opportunities to reverse power relations between the master of the house and the staff. The departure of the cook's son, Biju, for the United States, creates an opening in the cook's mind, whose fantasy is clearly spelled out: "One day his son would accomplish all that Sai's parents had failed to do, all the judge had failed to do" (85). The judge is presented as an example of failure, and the cook is asking for revenge for his life of servitude in an inversion of social roles through the next generation.

The cook's importance in the text is reinforced by his role as storyteller, as he is the one who remembers the judge's past and narrates it to Sai. In addition, the very presence of Biju's story, intertwined in the narrative of the events of Kalimpong and of the judge's past, testifies to the change of perspective which is operated in The Inheritance of Loss. In novels such as Jane Eyre or Mansfield Park, the departure of some characters from the house is only evoked through the prism of those who remain, while in The Inheritance of Loss, the narration integrates the point of view of the cook's son, who has left India, and ends when his trip ends. The country house is not the only setting for the narration. The inclusion of narratives outside its walls suggests that the story requires a contrapuntal reading as defined by Edward W. Said in Culture and Imperialism: "a simultaneous awareness both of the metropolitan history that is narrated and of those other histories against which (and together with which) the dominating discourse acts" (59). In his analysis of Mansfield Park, Said argues that Sir Thomas Bertram, the owner of Mansfield Park, is never 
seen as present in Antigua (108), where he goes for business purposes. Hence the focus is mostly on the country house estate and a contrapuntal reading shows, for instance, that the Bertrams' fortune depends on the slave trade, sugar and the colonial planter class (112).

A reading of The Inheritance of Loss in this light underscores the novel's detachment from the model of the manor house novel. The alternating chapters, which centre on life in Kalimpong and Biju's trajectory in the United States, as well as the focus on characters who do not belong to the social circles of the anglophile community, prevent a univocal perception of the story as the reader is constantly asked to question the consequences of imperialism on members of various social classes, particularly in terms of international mobility. The Inheritance of Loss notably distinguishes narratives of elite and labour migrations in the discrepancy between the stories of Lola's and Mrs Sen's daughters in England and the U.S., which highlight economic and social success, and the reports of the cook's son, Biju. In this regard, being a "foreigner" is sometimes the privilege of an educated, well-off part of society. If both Pixie (Lola's daughter) and Biju have been led towards England and the U.S., respectively, only Pixie's voice can be heard from India. As a BBC reporter, she is on the airwaves every evening, her voice easily crossing miles to be heard by her proud mother from her cottage (47). Biju's voice, on the other hand, is barely audible on a rare phonecall to his father (230), and even his letters, soaked in water, cannot be read by the cook for whom they embody the "ocean between him and his son" (120). In her article "Disjunctures and Diaspora in Kiran Desai's The Inheritance of Loss", Oana Sabo remarks that Desai warns her readers against "exclusively celebratory views of diaspora" (388). Her focus on Biju's immigration attests to the necessity of telling the other side of the story, for his silencing through usual means of communication with his father suggests that his voice may not be heard otherwise. The comparison between these experiences of immigration confirms that the social statuses of characters remain unchanged by their geographical location: in India as abroad, the cook's son remains stuck to an inferior economic position. Hence Biju's return is motivated by his nostalgia for India and his wish not to be a foreigner anymore, as attested by his first impressions after landing on the Indian soil when returning from the United States:

Sweet drabness of home - he felt everything shifting and clicking into place around him, felt himself slowly shrink back to size, the enormous anxiety of being a foreigner, ebbing that unbearable arrogance and shame of the immigrant. (300) 
Contrarily to the earlier occurrences of the word in the novel, here "foreigner" is not perceived as a position to be looked for but as a source of anxiety, highlighting a stark contrast between the Kalimpong community of surrogate Britons and the immigrant who misses home. The impossibility of finding a place of belonging in a foreign community brings Biju back to his roots, which corresponds to the lifting of a weight. By shrinking back to size, getting smaller, Biju seems to regain his original identity although it is expressed by a loss of size and later, of money. In the authenticity of this feeling, the character proves to be aware of the fragility of an identity which he does not attempt to build up artificially; he does not reject the "drabness of home" by preferring an economic or at least social form of success. Biju arrives almost naked, robbed, deprived of all his belongings, but his return home signs the end of the story, while all the other characters' fates remain uncertain.

In The Inheritance of Loss, the characters' attempt at being foreigners in their own country, through their celebration of the country house, leads to the establishment of a nostalgia which, despite its authenticity as a feeling, is mostly used as a social tool to affirm power and superiority, and the belonging to a group which sets itself apart from others. If the British country house presents itself as a model for the characters of The Inheritance of Loss, this ideal is questioned by the political situation which intrudes inside these very houses and prevents the model from coming true. While the British country house does enable characters to soothe their nostalgia, the sense of home that it provides does not seem sustainable any longer and the houses tellingly start to crumble. Hence while in Mansfield Park Fanny dreams of returning to her uncle's stable, comfortable country house, it is no surprise that Sai wishes to leave.

The study of Kiran Desai's novel underlines how nostalgia and the allegiance to a country of adoption can shape one's place in society while creating or reinforcing social lines of distinction. It also suggests that the choice of one's country of belonging, or homeland, entails the reassessment of one's ethics, which Su refers to as he analyses the links between space and ethos: "Place limits individuals by locating them within a community; freedom from place, on this understanding, implies the freedom to redefine oneself according to the pattern of one's own making" (24). I would argue that the characters' apparent subscribing to a British ethos is a subverted way of accepting an aging Indian ethos which values British culture more than Indian ones, for the screen of colonialism still hovers on Kalimpong. Sai's departure 
from Cho Oyu, then, is a hopeful perspective, a displacement which announces an ethical journey through the confrontation with other stories, as opposed to the enclosing motion of her grandfather for, she realises: "Never again could she think there was but one narrative and that this narrative belonged only to herself, that she might create her own tiny happiness and live safely within it" (323). Sai promises herself to include others' narratives in a metafictional echo of what the novel proposes to do. Through the parody of the genre of the manor house novel and the increasing number of stories in a fragmented narrative, The Inheritance of Loss invites its readers to incorporate contrapuntal readings to debunk the myth of ever-successful diasporic movements towards the West.

\section{Works Cited:}

Austen, Jane. Mansfield Park. 1814. Oxford: Oxford UP, 2003. Print. Bhabha, Homi K. The Location of Culture. London: Routledge, 1994. Print.

Desai, Kiran. The Inheritance of Loss. 2006. London: Penguin Books, 2007. Print.

Hutcheon, Linda. A Theory of Parody: The Teachings of TwentiethCentury Art Forms. New York: Methuen, 1985. Print.

Ishiguro, Kazuo. The Remains of the Day. London: Faber and Faber, 1989. Print.

James, Henry. English Hours. Boston: Houghton Mifflin, 1905. Print.

Loh, Lucienne. "Comparative Postcolonial Ruralities and English Heritage: Julian Barnes's England, England and Kiran Desai's The Inheritance of Loss". The Journal of Commonwealth Literature 51.2 (2016): 302-315. Web. 30 Dec. 2017.

Kelsall, Malcolm Miles. The Great Good Place: The Country House and English Literature. London: Harvester Wheatsheaf, 1993. Print.

Mandler, Peter. The Fall and Rise of the Stately Home. New Haven: Yale UP, 1997. Print.

Mistry, Rohinton. Tales from Firozsha Baag. London: Faber and Faber, 2006. Print.

Naipaul, V. S. The Mimic Men. 1967. London: Penguin, 1994. Print.

Roy, Arundhati. The God of Small Things. 1997. New Delhi: Penguin, 2002. Print.

Rushdie, Salman. Imaginary Homelands: Essays and Criticism 1981 1991. London: Granta, 1992. Print.

Sabo, Oana. "Disjunctures and Diaspora in Kiran Desai's The Inheritance of Loss". The Journal of Commonwealth Literature 47.3 (2012): 375-392. Web. 30 Dec. 2017. 
Said, Edward W. Culture and Imperialism. London: Vintage, 1994. Print. $\mathrm{Su}$, John J. Ethics and Nostalgia in the Contemporary Novel. Cambridge : Cambridge UP, 2005. Print.

\section{HABITER LA COUNTRY HOUSE BRITANNIQUE EN INDE : LA PERTE EN HERITAGE, DE KIRAN DESAI}

Le roman de Kiran Desai, La Perte en héritage, acclamé par la critique, entrelace les parcours de trois personnages : le juge, hanté par son passé, est rejoint par sa petite fille Sai dans sa maison au nordest de l'Inde, tandis que le fils de son cuisinier travaille illégalement en Amérique. Publié en 2006, le roman a été principalement analysé dans le cadre des études sur la diaspora, et apprécié pour sa remise en question des effets de la mondialisation et de l'immigration. II convient également d'analyser la manière dont certains personnages du roman, parmi lesquels le juge, choisissent d'habiter leur maison comme des étrangers ou, plus spécifiquement, comme des Britanniques de substitution dans leur pays d'origine, créant ainsi une communauté distincte d'anglophiles. Le " réconfort d'être un étranger dans [leur] propre pays " récompense les personnages qui imitent un mode de vie britannique. Les maisons sont situées en Inde, après I'Indépendance ; cependant cet article interroge la façon dont elles peuvent être vues comme des pendants de la country house britannique, notamment dans la conservation de leur lien avec les valeurs de continuité et de tradition, et par leur caractère proprement anglais. Bien que les personnages prennent la country house britannique comme modèle pour leur maison en Inde, ils éprouvent une nostalgie pour une maison britannique qu'ils n'ont jamais connue ou possédée. Leur expérience d'immigration ne les conduit qu'à la création d'un pastiche de la country house anglaise, qui repose sur une vision mythique de l'Angleterre. Leur assimilation de valeurs et d'une hiérarchie sociale anglaises en fait des étrangers dans leur propre pays, troublant ainsi la démarcation entre " pays d'origine » et " étranger ». Par ailleurs, leur choix du modèle de la country house britannique souligne la façon dont La Perte en héritage parodie le genre du manor house novel et son adhésion aux normes coloniales.

Keywords: maison, nostalgie, country house, roman de la manor house, littérature postcoloniale. 